\title{
Private Investment Demand Function in Bangladesh: An ARDL Approach
}

\author{
Harun Bal1 ${ }^{1}$, Abdullahil Mamun², Mohammad Masrurul Mowla ${ }^{3}$, Nazamul Hoque ${ }^{4}$, Md. Zahid Hossain Bhuiyan ${ }^{5}$ \\ ${ }^{1}$ Professor, Department of Economics, Faculty of Economics \& Administrative Sciences, Cukurova University, Adana, TURKEY \\ ${ }^{2}$ Research Fellow, The Scientific and Technological Research Council of Turkey (TUBITAK), Ankara, TURKEY \& Associate Professor, \\ Department of Business Administration, Faculty of Business Studies, International Islamic University Chittagong, Chittagong, BANGLADESH \\ ${ }^{3,4}$ Associate Professor, Department of Business Administration, Faculty of Business Studies, International Islamic University Chittagong, \\ Chittagong, BANGLADESH \\ ${ }^{5}$ Assistant Professor, Department of Business Administration, Faculty of Business Studies, International Islamic University Chittagong, \\ Chittagong, BANGLADESH \\ *E-mail for correspondence: ahm.economics@gmail.com
}

https://doi.org/10.18034/abr.v9i1.248

\begin{abstract}
Investment, as an addition to the existing physical stock of capital, contributes to the growth of Bangladesh economy in a decisive way. Therefore, factors that determine the private investment need to be studied in order to frame policies to manage them so as to achieve the desired capital stock for the economy to accomplish the much higher GDP growth objective in coming years. The study, thus, is an attempt to estimate the private investment demand function of Bangladesh.

It employees the ARDL bounds testing approach to investigate the relationship between private investment spending and its regressors, namely, real income, rental cost of capital, foreign direct investment and exchange rate relying on data for the period 1980-2017.

The study identifies a long-run equilibrium relationship between private investment spending and its determinants. The determinants are found to have conventional signs- while a rise in real income boosts private investment spending, a rise in the rental cost of capital hurts it. While most of the earlier studies compared the relative role of public and private investment in economic growth of Bangladesh, studies on the factors that determine the countries investment spending is very few. Moreover, majority of the studies in the latter group focuses on determinants of gross investment in Bangladesh, while the study focuses on the domestic private investment taking most recent years' data in the sample period.
\end{abstract}

Key words: Private Investment, Capital Stock, ARDL Bounds Test, Bangladesh

JEL Classification Codes: E20, E22

\section{INTRODUCTION}

Economic growth of an economy largely depends on the development of productive capacity of the economy. Being an addition to the existing physical stock of capital, investment builds this productive capacity and hence contributes to the growth of an economy in a decisive way. Capital can be increased both qualitatively and quantitatively, and these increase in capital increases labor productivity which has a direct impact on economic growth. Economists view investment spending as the most volatile component of aggregate demand and hence liable for change in output level in alternating periods of the business cycle (Baumol \& Blinder, 2015; Dornbusch et al., 2011). The dual role that investment plays in the course of development of an economy is shown in figure 1. Along with fostering capital accumulation, it enhances aggregate demand and thereby leads to greater output level.

Figure 1: Role of Investment in Output Growth

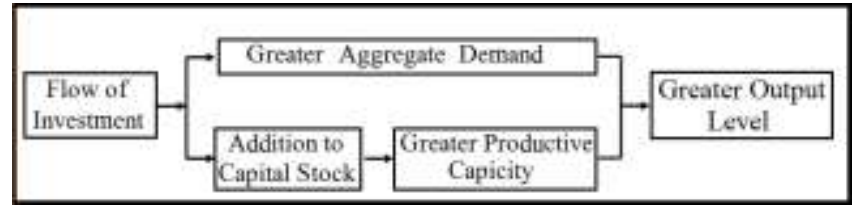


Private investment, generally referred to as the purchase of capital assets by private entrepreneurs with anticipation of generating profit, fosters industrial growth and thereby generates income and employment opportunity in an economy (Mamun and Islam, 2010). A good number of studies investigate the impact of investment on economic growth and suggest that the investment incurred by the private sector has much higher impact on economic growth than that of public investment (Munnell, 1990; Khan and Reinhart 1990; Khan and Kumar, 1997).

The economy of Bangladesh experiences a sustained increase in the growth rate of GDP. The growth rate of GDP that was 1.06 percent in the 1970s increased to 6.6 percent in the 2010s. On the other hand, its private investment rises from 3.73 percent to 22.6 percent of GDP over the same period. Therefore, private investment seems to have a considerable impact on GDP growth of Bangladesh economy. Rahman (2016) also identifies that private investment exerts a greater impact on the growth of GDP per capita than public investment in Bangladesh. Therefore, factors that determine the private investment need to be studied in order to frame policies to manage them so as to achieve the desired capital stock for the economy to accomplish the much higher GDP growth objective in coming years. With this backdrop, the study is an attempt to investigate the factors that determine the domestic private investment spending of Bangladesh.

\section{InVESTMENT COMPOSITION \& GROWTH PERFORMANCE}

GDP growth performance in Bangladesh has been good. The highest Growth is averaged as $7.42 \%$ per annum over the period $2016-2018$. It was $3.85 \%$ in the 1980 s, $4.61 \%$ in $1990 \mathrm{~s}$ and 5.58 in 2000s. Our objective is to raise it to the 8$9 \%$ range by 2021 . Growth has been reinforced by the revival in private investment; which increased by $15 \%$ annually, increasing its part in GDP from $22.16 \%$ in 2011 to $23.26 \%$ in 2018 . The share of public investment in the meantime is increased from $5.25 \%$ to about $8 \%$ (see table 2). The growth rate over 6 percent throughout the current decade is accompanied by investment growth in the private sector thanks to the incredible development of its stock market (Mamun et al., (2018).

The composition of growth of investment has been shown in table 01. The composition of investment growth has undergone changes during the last one and half decades. As shown in Table, the annual growth rate of private investment declined after 1998 with recovery from 2001 to 2006.

Table 1: The Composition of Growth of Investment

\begin{tabular}{|c|c|c|c|c|c|c|}
\hline Year & $\begin{array}{c}\text { Total } \\
\text { Investment }\end{array}$ & $\begin{array}{c}\text { Public } \\
\text { Investment }\end{array}$ & $\begin{array}{c}\text { Private } \\
\text { Investment }\end{array}$ & $\begin{array}{c}\text { Growth of total } \\
\text { Investment }\end{array}$ & $\begin{array}{c}\text { Growth of Public } \\
\text { Investment }\end{array}$ & $\begin{array}{c}\text { Growth of Private } \\
\text { Investment }\end{array}$ \\
\hline 2011 & 2511.3 & 481.5 & 2029.8 & 19.968 & 29.158 & 17.977 \\
\hline 2012 & 2982.3 & 608 & 2374.2 & 18.755 & 26.272 & 16.967 \\
\hline 2013 & 3403.7 & 796.2 & 2607.5 & 14.130 & 30.954 & 9.826 \\
\hline 2014 & 3839.9 & 879.9 & 2960 & 12.815 & 10.512 & 13.519 \\
\hline 2015 & 4378.6 & 1033.9 & 3344.7 & 14.029 & 17.502 & 12.997 \\
\hline 2016 & 5138.4 & 1154.9 & 3983.5 & 17.353 & 11.703 & 19.099 \\
\hline 2017 & 6028.3 & 1464.7 & 4563.6 & 17.319 & 26.825 & 14.563 \\
\hline 2018 & 7029.4 & 1794.2 & 5235.2 & 16.607 & 22.496 & 14.716 \\
\hline
\end{tabular}

Source: Bangladesh Economic Review, 2018.

Therefore, a complementary association between private and public investment have been noticed and thereby an acceleration of the growth of total investment can be a critical driving force to sustained economic growth.

Again, higher investment-GDP ratio leads to high economic growth, which is still lower in Bangladesh, but it is gradually rising. The investment-GDP ratio is rising sharply especially in the private sector, it was $3.73 \%$ in the 1970 s and in the period 2010s it stops at $16.94 \%$. On the contrary, in the public sector, the investment/GDP ratio is still moving around $6.8 \%$.

Though the share of total investment in GDP goes on rising, public investment has a little role in the rise. Therefore, it is the private investment that pays the vital role in raising the share of total investment in GDP. Moreover, as the investment-GDP ratio is noticeably growing in the public sector, therefore we can conclude that an acceleration of investment and especially private investment is essential for fostering economic growth.

Table 2: Investment-GDP ratio, An Indicator of Economic Growth

\begin{tabular}{|c|c|c|c|}
\hline Period & $\begin{array}{c}\text { Total Investment } \\
\text { as percent of } \\
\text { GDP }\end{array}$ & $\begin{array}{c}\text { Private } \\
\text { Investment as } \\
\text { percent of GDP }\end{array}$ & $\begin{array}{c}\text { Public } \\
\text { Investment as } \\
\text { percent of GDP }\end{array}$ \\
\hline $1970 \mathrm{~s}$ & 10.64 & 3.73 & 6.91 \\
\hline $1980 \mathrm{~s}$ & 13.10 & 6.97 & 6.13 \\
\hline $1990 \mathrm{~s}$ & 18.60 & 9.78 & 8.82 \\
\hline $2000 \mathrm{~s}$ & 25.39 & 20.09 & 5.30 \\
\hline $2010 \mathrm{~s}$ & 29.46 & 22.60 & 6.85 \\
\hline
\end{tabular}

Source: Bangladesh Economic Review, 2018 


\section{DatA AND Methodology}

\section{Data Sources}

The study examines the determinants of investment spending. Following the Neoclassical theory of investment, two major determinants of private investment spending are rental cost of capital (i.e., the interest rate) and income level of an economy. Higher interest rate reduces investment spending raising the opportunity cost while higher income level of an economy leads to higher investment. Harrison \& McMillan (2003) and Markusen \& Venables (1999) accept foreign direct investment (FDI) as one of the crucial factors of domestic investment while Ali (2013) accepts exchange rate. Hence, the study considers domestic real income level measured in terms of real GDP, real interest rate, foreign direct investment and exchange rate as the major influential factors of domestic investment based on available literature survey. The study depends on annual time series data through 1981-2017. There are different sources of the variables. Table- 3 offers basic explanations of selected variables together with their sources.

Table 3: Variables, Explanations and Sources

\begin{tabular}{|c|c|c|}
\hline Variable & Explanation & Source \\
\hline INV & Domestic Private Investment & $\begin{array}{c}\text { Bangladesh } \\
\text { Economic Review, } \\
\text { Various Issues } \\
\end{array}$ \\
\hline $\mathrm{Y}$ & Real GDP & \multirow{4}{*}{$\begin{array}{c}\text { World } \\
\text { Development } \\
\text { Indicators, World } \\
\text { Bank, } 2016\end{array}$} \\
\hline $\mathrm{r}$ & $\begin{array}{l}\text { Real Interest Rate: Inflation- } \\
\text { adjusted lending interest rate }\end{array}$ & \\
\hline FDI & Foreign Direct Investment & \\
\hline $\mathrm{E}$ & $\begin{array}{l}\text { Exchange Rate: Local currency } \\
\text { for per unit U.S. dollar }\end{array}$ & \\
\hline
\end{tabular}

\section{Model and Methodology}

In order to identify the long term determinants of domestic private investment spending, the study will check whether there prevail any long-run cointegrating relationships among time series variables. It can be done applying the Johansen's (1988) approach to cointegration and ARDL or Bounds testing methodology offered by Pesaran and Shin (1999). The approach of Johansen is applicable when all the time series variables are integrated at order one and the sample size should be sufficiently large in order to avoid small sample bias. On the other hand, ARDL Bounds Testing approach can be applied even if the series are integrated at order zero or order one or a combination of both and the estimators obtained are less sensitive to the sample size (Pesaran et al., 2001). Therefore, order of integration of the series need to be tested so as to identify the appropriate method of detecting long-run cointegration relationship among the variables.

The conventional techniques named ADF (Augmented Dickey-Fuller) and PP (Phillips Perron) Unit Root Tests are commonly used to detect the stationarity of the time series variables. Outcomes of the tests are shown below in table-4. As per test results, domestic private investment, real income shown by real GDP and foreign direct investment are stationary at first difference. Therefore, these three variables follow I(1) processes. Though the PP test finds the exchange rate is stationary at level, visual check suggests that it is nonstationary. Finally, the real interest rate is stationary at level, that is, it is an $\mathrm{I}(0)$ scheme. Regression at level of the variables will be spurious in the presence of I(1) series and in this case the variables have to pass the cointegration test. Since the case we are handling contains both $\mathrm{I}(0)$ and $\mathrm{I}(1)$ variables and the sample size is relatively small, employing the ARDL Bounds Testing approach will be suitable for researching the long run cointegrating relationship among the variables.

Table 4: ADF and PP Tests for Stationarity

\begin{tabular}{|c|c|c|c|c|c|c|}
\hline \multirow{2}{*}{ Variables } & \multirow{2}{*}{ Test in } & \multirow{2}{*}{ Includes } & \multicolumn{2}{|c|}{ ADF } & \multicolumn{2}{|c|}{$\mathrm{PP}$} \\
\hline & & & t-statistic & p-value & t-statistic & $\mathrm{p}$-value \\
\hline \multirow{4}{*}{$\ln \mathrm{I}$} & \multirow{2}{*}{ Level } & Intercept & 2.247 & 1.000 & 1.988 & 1.000 \\
\hline & & Trend, Intercept & -3.802 & 0.032 & -1.416 & 0.839 \\
\hline & \multirow{2}{*}{ First Difference } & Intercept & -5.171 & $0.000^{*}$ & -5.372 & $0.000^{*}$ \\
\hline & & Trend, Intercept & -2.723 & 0.236 & -6.011 & $0.000^{*}$ \\
\hline \multirow{4}{*}{$\ln Y$} & \multirow{2}{*}{ Level } & Intercept & 6.523 & 1.000 & 9.367 & 1.000 \\
\hline & & Trend, Intercept & -0.849 & 0.951 & -0.837 & 0.952 \\
\hline & \multirow{2}{*}{ First Difference } & Intercept & -4.211 & $0.002^{*}$ & -4.347 & $0.002^{*}$ \\
\hline & & Trend, Intercept & -6.171 & $0.000^{*}$ & -7.627 & $0.000^{*}$ \\
\hline \multirow{2}{*}{$\mathrm{i}$} & \multirow{2}{*}{ Level } & Intercept & -3.764 & $0.007^{*}$ & -3.692 & $0.009^{*}$ \\
\hline & & Trend, Intercept & -3.264 & $0.092 * *$ & -3.593 & $0.045^{*}$ \\
\hline \multirow{4}{*}{$\operatorname{lnFDI}$} & \multirow{2}{*}{ Level } & Intercept & -1.243 & 0.643 & -0.705 & 0.833 \\
\hline & & Trend, Intercept & -1.729 & 0.716 & -2.613 & 0.277 \\
\hline & \multirow{2}{*}{ First Difference } & Intercept & -1.584 & 0.478 & -7.562 & $0.000^{*}$ \\
\hline & & Trend, Intercept & -5.787 & $0.000^{*}$ & -7.455 & $0.000^{*}$ \\
\hline \multirow{4}{*}{$\ln E$} & \multirow{2}{*}{ Level } & Intercept & -2.520 & 0.120 & -3.901 & $0.005^{*}$ \\
\hline & & Trend, Intercept & -1.681 & 0.738 & -3.785 & $0.029^{*}$ \\
\hline & \multirow{2}{*}{ First Difference } & Intercept & -4.831 & $0.000^{*}$ & -6.109 & $0.000^{*}$ \\
\hline & & Trend, Intercept & -5.598 & $0.000^{*}$ & -13.259 & $0.000^{*}$ \\
\hline
\end{tabular}


The functional relationship between private domestic investment spending and its determinants derived from the literature survey, namely, real domestic income, real interest rate, foreign direct investment and exchange rate, can be given as follows-

$$
\ln I N V=f(\ln Y, r, \ln F D I, \ln E)
$$

The cointegrating regression model in the long-run and the ARDL model according to the traditional ECM for cointegrating variables will be as follows-

$$
\begin{aligned}
& \ln I N V_{t}=\alpha_{0}+\alpha_{1} \ln Y_{t}+\alpha_{2} r_{t}+\alpha_{3} \ln F D I_{t}+\alpha_{4} \ln E_{t}+u_{t} \\
& \Delta \ln I N V_{t}=\phi+\sum \varphi_{i} \Delta \ln I N V_{t-i}+\sum \gamma_{j} \Delta \ln Y_{t-j}+\sum \eta_{k} \Delta r_{t-k}+\sum \lambda_{l} \Delta \ln F D I_{t-l}+\sum \mu_{m} \Delta \ln E_{t-m}+\theta E C T_{t-1}+e_{t}
\end{aligned}
$$

Here, the error-correction term (ECT) is the series of OLS residuals derived from the long run model (2). The real domestic income is proxied by real GDP. Real GDP, foreign direct investment and exchange rate depreciation reflected by an increase in the exchange rate is expected to have positive impacts on domestic private investment while higher real interest rate of dispirits entrepreneurs to borrow and to invest. Thus, the plausible signs of the coefficients, in the long run, are $\alpha_{1}>0, \alpha_{2}<0, \alpha_{3}>0, \alpha_{4}>0$.

\section{EMPIRICAL RESULTS AND Discussion}

The ARDL Bounds Tests is applied in order to examine if there is a long-run relationship among the variables. Table 5 shows the results of Bounds test. As the computed value of F-statistics exceeds the critical upper bond values, the null hypothesis of 'no long-run relationships exist' is not accepted and hence the variables are cointegrated in the long-run, meaning that no longterm information is lost if regression is performed at their levels.

Table 5: Bound test result

\begin{tabular}{|c|c|c|c|c|}
\hline \multirow{2}{*}{ Variable } & \multirow{2}{*}{ F-statistics } & \multicolumn{3}{|c|}{ Critical Value Bounds* } \\
\cline { 3 - 5 } & & Significance & $\begin{array}{c}\text { Lower } \\
\text { Bound }\end{array}$ & $\begin{array}{c}\text { Upper } \\
\text { Bound }\end{array}$ \\
\hline \multirow{3}{*}{$\begin{array}{c}\text { Investment } \\
\text { Spending }\end{array}$} & \multirow{2}{*}{6.376117} & $10 \%$ & 2.2 & 3.09 \\
\cline { 3 - 5 } & & $5 \%$ & 2.56 & 3.49 \\
\cline { 3 - 5 } & & $2.50 \%$ & 2.88 & 3.87 \\
\cline { 3 - 5 } & & $1 \%$ & 3.29 & 4.37 \\
\hline
\end{tabular}

Note: Pesaran Critical Values
The existence of a cointegrating relationship in the longrun allows us to estimate the dynamics in the short-run and the adjustment to the long-run equilibrium. Based on AIC (Akaike Information Criteria), an ARDL $(1,2,0,1,2)$ model is appropriate for the estimation of long-run cointegrating relationship. The model is stable and free from the problem of serial correlation which justifies the results of Bounds test. Table 6 offers the dynamic shortrun error correction model for ARDL $(1,2,0,1,2)$ scheme. A negative significant coefficient attached to the errorcorrection term ECTt-1 measures the speed at which short-run errors are adjusted towards the equilibrium in the long-run. The obtained coefficient of the ECT is negative and statistically significant which is '-0.588' meaning that any deviation in domestic private investment in the short-rum adjusted at the rate of 58.8 percent per annum to its long-run equilibrium value.

Table 6: Error-correction Estimate for ARDL Model

\begin{tabular}{|c|c|c|c|c|}
\hline Variable & Coefficient & Std. Error & t-Statistic & Prob. \\
\hline $\mathrm{D}(\ln \mathrm{Y})$ & 0.581 & 0.233 & 2.491 & 0.021 \\
\hline $\mathrm{D}(\ln \mathrm{Y}(-1))$ & -0.353 & 0.250 & -1.410 & 0.173 \\
\hline $\mathrm{D}(\ln \mathrm{FDI})$ & 0.005 & 0.003 & 1.740 & 0.097 \\
\hline $\mathrm{D}(\ln \mathrm{E})$ & 0.134 & 0.077 & 1.743 & 0.092 \\
\hline $\mathrm{D}(\ln \mathrm{E}(-1))$ & -0.111 & 0.064 & -1.741 & 0.100 \\
\hline $\mathrm{ECT}(-1)$ & -0.588 & 0.085 & -6.882 & 0.000 \\
\hline
\end{tabular}

Table 7: Long-run Model for Domestic Private Investment

\begin{tabular}{lccccc}
\hline $\ln I_{t}=$ & -5.082 & $+1.227 \ln Y_{t}-$ & 0.005 & $I_{t}+0.021 \ln F D I_{t}+0.257 \ln E_{t}+e_{t}$ \\
$S e$ & 0.351 & 0.053 & 0.002 & 0.005 & 0.083 \\
$t$ & $-14.473^{\circ}$ & $22.947^{\circ}$ & $-2.951^{\circ}$ & $4.177^{\circ}$ & $3.110^{\circ}$ \\
\hline
\end{tabular}

Note: * indicates coefficients are significant at 1 percent significance level

With regard to the long-run relationship (equation 2) between private domestic investment and its determinants as shown in table 7 , the estimated coefficients of the variables have signs theoretically expected and highly significant at 1 percent confidence level. The responsiveness of domestic private investment to 1 percent change in real income is 1.23 percent and positive. Islam (2003) measures the investment sensitivity to interest rate and also identifies similar result in terms of direction. The interest rate sensitivity of investment is 0.005 percent which is inverse. A 1 percent decrease in real interest rate lessens domestic private investment by 0.005 
percent. FDI inflow is complementary to domestic investment. Depreciation of real effective exchange rate promotes domestic entrepreneurs to invest more enhancing competitiveness confirmed by the positive coefficient of the exchange rate.

\section{POLICY IMPLICATIONS AND CONCLUSION}

The study supports the view that easing credit constraint by reducing the rental cost of capital, i.e., the interest rate can be a way to attract more investment in Bangladesh economy. According to the WDI, cross country comparison indicates that real interest rate is relatively high in Bangladesh which has an ominous impact on private investment and therefore on the growth of the economy. The study also confirms that income growth can draw more private investment in Bangladesh economy. In current years, Bangladesh receives substantial FDI in its infrastructure sector. Efficient physical infrastructure is still one of the major hitches of the economy. Hence, FDI in infrastructure plays an important role in tempting more private investment in the economy. The complementary role of FDI on private investment directs policymakers to set comprehensive policies for long-term investment both from home and abroad and maintain economic growth for advancing towards desired goals of the economy.

\section{REFERENCES}

Ali, S. (2013), A Cointegration Approach to Estimate Private Investment Demand Function of Pakistan, Asian Journal of Research in Business Economics and Management, Vol. 3, No. 9, pp. 1-13.

Baumol, W. J., \& Blinder, A. S. (2015), Microeconomics: Principles and policy. Nelson Education, Toronto.

Dornbusch, R., Fischer S. \& Startz R. (2011), Macroeconomics, 11th ed., McGraw-Hill, New York

Harrison, A. E., \& McMillan, M. S. (2003), Does direct foreign investment affect domestic credit constraints? Journal of International Economics, Vol. 61, pp 73-100. https:/ / doi.org/10.1016/S0022-1996(02)00078-8
Islam, M. E., \& Begum, M. N. (2005), Is Investment Demand Sensitive to Interest Rate in Bangladesh?-An Empirical Analysis, Bank Parikrama, Vol. 30, No 1, pp 69-86.

Johansen, S. (1988), Statistical Analysis of cointegration Vectors, Journal of Economic Dynamics and Control, Vol. 12, pp 231-254.

Khan, M. and Kumar, M.S. (1997), Public and private investment and the growth process in developing countries, Oxford Bulletin of Economics and Statistics, Vol. 59, pp.69-88.

Khan, M. and Reinhart, C.M. (1990), Private investment and economic growth in developing countries, World Development, Vol. 18, No. 1, pp.19-27.

Mamun, A. and Islam S. (2010), Investment Pattern for Required Economic Growth to Achieve Poverty Reduction Targets, The Cost and Management, Vol. 38, No. 5, pp. 29-31.

Mamun, A., Ali, M. H., Hoque, N., Mowla, M. M., \& Basher, S. (2018), The Causality between Stock Market Development and Economic Growth: Econometric Evidence from Bangladesh, International Journal of Economics and Finance, Vol 10, No. 5, pp 212.

Markusen, J. R., \& Venables, A. J. (1999), Foreign direct investment as a catalyst for industrial development, European Economic Review, Vol 43, pp 335-356. https://doi.org/10.1016/S0014-2921(98)00048-8

Munnell, A.H. (1990), Why has productivity declined? Productivity and public investment, New England Economic Review, Vol. 30, pp.3-22.

Pesaran, M. H. and Shin, Y. (1999), "An Autoregressive Distributed Lag Modelling Approach to Cointegration Analysis", in S. Strom (ed), Econometrics and Economic Theory in the 20th Century: The Ragnar Frisch Centennial Symposium. 1998. Chapter 11, Cambridge University Press, Cambridge.

Pesaran, M. H., Shin, Y. and Smith, R. J. (2001), Bounds Testing Approaches to the Analysis of Level Relationship, Journal of Applied Econometrics, Vol. 16, pp 289-326.

Rahman, M., Islam, A. M., \& Banerjee, P. K. (2016), Public versus private investment in economic growth of Bangladesh: An econometric analysis, International Journal of Trade and Global Markets, Vol 9, No 3, pp 228-248. 
Online Archive: https://abc.us.org/ojs/index.php/abr/issue/archive 